\title{
Long Term Effect Organic, Inorganic and Integrated Nutrient Management on Rice-Wheat Cropping System
}

\author{
S.M. Kurmvanshi ${ }^{1}$, R.K. Tiwari ${ }^{2}$, B.M. Maurya ${ }^{1}$ and Smita Singh ${ }^{3^{*}}$ \\ ${ }^{1}$ All India Coordinated Research Project on Integrated Farming System, \\ College of Agriculture, JNKVV Rewa 486001 (M.P.), India \\ ${ }^{2}$ College of Agriculture, Rewa 486001 (M.P.), India \\ ${ }^{3}$ Krishi Vigyan Kendra, Rewa 486001 (M.P.), India \\ *Corresponding author
}

\section{A B S T R A C T}

\section{Keywords}

Rice, Wheat, Integrated nutrient management

Article Info

\section{Accepted:}

08 July 2018

Available Online:

10 August 2018
The experiment on long term effect organic, inorganic and integrated nutrient management on performance of rice-wheat cropping system was conducted from 2004-05 to 2016-17 at IFS sub centre Rewa (M.P.). The study reveals that the application of $100 \%$ NPK (N 120 $\mathrm{kg}, \mathrm{P}_{2} \mathrm{O}_{5} 60 \mathrm{~kg}$ and $\left.40 \mathrm{~kg} \mathrm{~K} 2 \mathrm{O} / \mathrm{ha}\right)+25 \mathrm{~kg}$ Zinc sulfate/ha based on soil test value for both crops gave rice yield $38.43 \mathrm{q} / \mathrm{ha}$ and wheat yield $40.15 \mathrm{q} / \mathrm{ha}$. The rate of increase in grain yield was $10.52 \%$ in rice and $17.98 \%$ in wheat as compared to conversion period. The integrated use of 50\% NPK and 50\% N through FYM gave maximum rice yield $38.09 \mathrm{q} / \mathrm{ha}$ and wheat yield $33.51 \mathrm{q} /$ ha which were $36.09 \%$ and $21.93 \%$ higher than conversion period. Among different organic farming packages grain yield of rice and wheat was increased over conversion period. The organic carbon status has been found to increase under different organic sources of nutrient management as compared to initial status. Available potash status was found to decrease under different organic, inorganic and integrated nutrient management practices as compared to initial status.

\section{Introduction}

RICE (Oryza sativa L.) - Wheat (Triticum aestivum L.) cropping system is a predominant cropping sequence in India. Approximately, 10.5 million hectare area comes under this cropping system and contributes 25 per cent of total food grain in India. About, 33 per cent of India's rice and 42 per cent of wheat are grown in this rotation. Nearly 63 per cent of total fertilizer used in the country is applied to rice and wheat crop alone. Rice and wheat are the important crops of Madhya Pradesh which occupy an area of 15.59 lakh hectare and 42.75 lakh hectare, respectively with the production of 14.62 tonnes and 78.47 lakh tonnes, respectively. The average productivity of rice is $989 \mathrm{~kg} / \mathrm{ha}$ and wheat is $1916 \mathrm{~kg}$ / ha.

There are indications of stagnation or even decline in the productivity of rice and wheat field due to decline in soil organic matter, over mining of nutrient reserve, loss of nutrients and non availability of cost effective 
fertilizers. The application of inorganic fertilizer even in balance form may not sustain the soil fertility and productivity under continuous rice-wheat cropping. However, integrated use of inorganic and organics including crop residues may improve the soil productivity (Chettry and Bandopadhyay, 2005 and Mankotia, 2007). Farm yard manure is proven source of nutrient in agricultural crops but its availability is quite inadequate (Mishra and Prasad, 2000).

Use of high analysis chemical fertilizers in imbalanced and indiscriminate manner has developed many problems like decline of soil organic matter, increase in salinity and sodicity, deterioration in the quality of crop produce, increase in hazardous pests and diseases and increase in soil pollutants (Chakraborti and Singh, 2004). In view of these facts, supply of all the plant nutrients has been advocated through organic 'sources only, but organic farming may not be feasible in modem commercial agriculture because it is unable to sustain high level of production to meet the food grain supply for the everincreasing population (Tarafdar et al., 2008).

Organic farming is a production system that avoids the use of synthetic chemical fertilizers, pesticides and growth regulating hormones and raises the crops with the use of organic manure, biofertilizers, oilcakes, crop rotation, legumes, green manure and biological pest control of rice and wheat. Continuous use of inorganic f ilizer have not only brought about loss of soil fauna and flora but also resulted in loss of secondary and micro nutrients in rice and wheat fields (Kharub and Chander, 2008).

Effect of different organic sources of manure like FYM, vermicompost, non edible oilcakes and biofertilizers in different combination have not been evaluated in scented rice and durum wheat under irrigated condition of
Rewa region of Madhya Pradesh. Keeping above facts in view present experiment was taken.

\section{Materials and Methods}

The present investigation was made on silty clay loam soil of All India Coordinated Research Project on Farming System, Kuthulia Farm, JNKVV, College of Agriculture, Rewa during kharif and rabi season of 2004-05 to 2016-17. The experimental field was low in available $\mathrm{N}$ (224 kg / ha) and Phosphorous (8.2 kg / ha) and high in available potash (315 kg / ha). The cropping system was rice in kharif and wheat in rabi. The same treatment and layout were adopted in both the crops for all the years in the same field.

The first three year period was considered as conversion period. The scented variety of rice PS-5 was transplanted at $20 \mathrm{~cm} \times 15 \mathrm{~cm}$ spacing on 2nd weeks of July in different years, in a non replicated randomized block design. The plot size was $20 \mathrm{~m} \times 10 \mathrm{~m}$ and year was taken as replication. The treatments were $\mathrm{T}_{1}: 50$ percent NPK through fertilizers + 50 per cent $\mathrm{N}$ through $\mathrm{FYM}, \mathrm{T}_{2}: 1 / 3 \mathrm{~N}$ each through FYM, vermicompost and Neem cake, $\mathrm{T}_{3}: \mathrm{T}_{2}+$ intercrop in Rabi as mustard with wheat in 4:1, $\mathrm{T}_{4}: \mathrm{T}_{2}+$ agronomic practices of weed control to both crop, T5: 50 per cent $\mathrm{N}$ as FYM + PSB. + Rock phosphate + Azospirilium, $\mathrm{T}_{6}: \mathrm{T}_{2}+$ Azospirilium $+\mathrm{PSB}$ and $\mathrm{T}_{7}$ : Recommended fertilizer dose $(120 \mathrm{~kg}$ N. $60 \mathrm{~kg} \mathrm{P}_{2} \mathrm{O}_{5}$ and $40 \mathrm{~kg} \mathrm{~K}_{2} \mathrm{O} / \mathrm{ha}$ ) The recommended fertilizer based on soil test value was $120 \mathrm{~kg} \mathrm{~N}, 60 \mathrm{~kg} \mathrm{P} 205$ and $40 \mathrm{~kg}$ $\mathrm{K} 20$ / ha + zinc sulphate $25 \mathrm{~kg} /$ ha for both the crops in $\mathrm{T}_{7}$ and $\mathrm{T}_{1}$. Wheat variety (durum) was HD 4672 and was sown in last week of November during all the years. All the recommended package of practices were adopted in both the crops. 


\section{Results and Discussion}

\section{(a) Effect on rice}

The grain yield of scented rice variety PS5 has been given in Table 1 reveals that grain yield of rice was maximum $38.61 \mathrm{q} / \mathrm{ha}$ under integrated use of $50 \% \mathrm{NKP}+50 \% \mathrm{~N}$ through FYM followed by $38.43 \mathrm{q} / \mathrm{ha}$ under $100 \%$ NPK given through fertilizer. It is due to the fact that organic and inorganic sources in integrated manner supply the essential element in available form as per need of the rice crop by which yield contributing character as well as growth parameter was increased in this treatment. Acharya et al., (1998) has also reported the positive effect of inorganic fertilizer on yield of rice. Among different organic sources of nutrient management grain yield of rice was maximum $36.69 \mathrm{q} / \mathrm{ha}$ in $\mathrm{T}_{3}$ in which $1 / 3 \mathrm{~N}$ through FYM, 1/3 $\mathrm{N}$ through vermi compost and $1 / 3 \mathrm{~N}$ through oil cake + intercropping of mustard + wheat was taken. The first three year period was considered as conversion period and response of different organic and inorganic sources of nutrient management was calculated. It is evident from the result that maximum increase in grain yield of rice was $70.07 \%$ in $\mathrm{T}_{3}$ followed by $62.75 \%$ in $\mathrm{T}_{4}$ over base year. Other organic sources of nutrient management gave $40.97 \%$ to $50 \%$ higher yield as compared to conversion period. The rate of increase in grain yield of rice was low $10.52 \%$ in $100 \%$ NKP given through fertilizer and $36.09 \%$ under $50 \%$ NPK given through fertilizer and $50 \% \mathrm{~N}$ through FYM in $T_{1}$. The rate of increase in grain yield of rice was higher under different organic sources of nutrient management as compared to $100 \%$ NPK given through fertilizer in $\mathrm{T}_{7}$ and $50 \%$ NPK given through fertilizer and $50 \% \mathrm{~N}$ through $\mathrm{FYM}$ in $\mathrm{T}_{1}$. Over conversion period (Adhikari and Mishra 2002, Khanda 2005 and Singh et al., 2000) also reported the positive effective of organic source of nutrient on physical and chemical properties of soil.

\section{(b) Effect on wheat}

The data pertaining to grain yield of durum wheat is presented in table 1 . It is clear that grain yield of wheat $40.15 \mathrm{q} / \mathrm{ha}$ was maximum in $\mathrm{T}_{7}$ were $100 \%$ NPK was given through fertilizer followed by $33.51 \mathrm{q} /$ ha in $\mathrm{T}_{1}$ where $50 \%$ NPK was given through fertilizer and $50 \% \mathrm{~N}$ through $\mathrm{FYM}$ in $\mathrm{T}_{1}$. It may be due to supply of nutrient in the available form as per need of the wheat crop by which growth and yield attributing characters were increased in $\mathrm{T}_{7}$. The similar finding was also reported by Maurya et al., (2010). The rate increase in grain yield as compared to conversion period over both year was $6 \%$ to $25.4 \%$ under different organic inorganic and integrated sources of nutrient management as compared to conversion period. The rate of increase in grain yield in wheat was maximum $25.4 \%$ in $\mathrm{T}_{4}$ followed by $21.93 \%$ in $\mathrm{T}_{1}$ while it was lowest in $\mathrm{T}_{6}$ as compared to conversion period. The response of organic, inorganic and integrated nutrient management system was lowest in wheat than rice.

\section{(c) Effect on rice - wheat system}

The wheat equivalent yield is presented in Table 2 reveals that wheat equivalent yield was maximum $81.42 \mathrm{q} /$ ha in $\mathrm{T}_{7}$ where $100 \%$ NPK was given through fertilizer followed by $73.13 \mathrm{q} /$ ha in $\mathrm{T}_{1}$ where $50 \%$ NPK was given through fertilizer and 50\% $\mathrm{N}$ through FYM. The treatment $\mathrm{T}_{3}$ gave higher wheat equivalent yield as compared to different organic sources of nutrient management. The rate of increased in wheat equivalent yield was $4.22 \%$ to $24.79 \%$ as compared to conversion period under different organic inorganic and integrated nutrient management system. 
Table.1 Effect of organic farming packages on grain yield of rice and wheat

\begin{tabular}{|c|c|c|c|c|c|c|}
\hline \multirow[t]{2}{*}{ Treatment } & \multicolumn{2}{|c|}{$\begin{array}{c}\text { Before conversion } \\
\text { period average } \\
\text { (2004-05 to 2006-07) }\end{array}$} & \multicolumn{2}{|c|}{$\begin{array}{c}\text { Mean of } \\
2007-2017\end{array}$} & \multicolumn{2}{|c|}{$\begin{array}{l}\text { \% increase over } \\
\text { conversion period }\end{array}$} \\
\hline & Rice & Wheat & Rice & Wheat & Rice & Wheat \\
\hline $\begin{array}{l}\mathrm{T}_{1} 50 \% \text { NPK through fertilizer }+50 \% \mathrm{~N} \\
\text { through FYM to both crops }\end{array}$ & 28.37 & 32.79 & 38.61 & 33.51 & 36.09 & 21.93 \\
\hline $\begin{array}{l}T_{2}-1 / 3 \mathrm{~N} \text { through } \mathrm{FYM} \text { vermicompost and } \\
\text { Neem cake to both the crops }\end{array}$ & 21.56 & 18.43 & 31.56 & 20.37 & 46.38 & 10.52 \\
\hline$T_{3}-T_{2}+$ Trap crop mustard in wheat & 21.52 & $\begin{array}{l}16.24 \mathrm{~W} \\
0.80 \mathrm{M}\end{array}$ & 36.60 & $\begin{array}{l}17.86 \\
2.85\end{array}$ & 70.07 & 9.95 \\
\hline $\begin{array}{l}T_{4}-T_{2}+\text { Agronomic practices of weed control } \\
\text { of to both the crops }\end{array}$ & 21.48 & 16.18 & 34.96 & 20.29 & 62.75 & 25.40 \\
\hline $\begin{array}{l}\mathrm{T}_{5^{-}} \mathbf{5 0} \% \mathrm{~N} \text { as } \mathrm{FYM}+\mathrm{PSB}+\text { rockphosphate+ } \\
\text { Azatobactor }\end{array}$ & 21.99 & 16.26 & 31.88 & 17.73 & 44.97 & 9.04 \\
\hline$T_{6}-T_{2}+$ Azatobactor + PSB & 23.81 & 18.83 & 35.72 & 19.96 & 50.02 & 6.00 \\
\hline $\begin{array}{l}\mathrm{T}_{7}-100 \% \mathrm{NPK}+25 \mathrm{~kg} \mathrm{ZnSo} 4 \text { based on soil } \\
\text { test value }\end{array}$ & 34.77 & 34.03 & 38.43 & 40.15 & 10.52 & 17.98 \\
\hline
\end{tabular}

Table.2 Effect of organic farming packages on wheat equivalent yield q/ha and net profit Rs/ha

\begin{tabular}{|c|c|c|c|c|c|c|}
\hline \multirow[t]{2}{*}{ Treatment } & \multicolumn{3}{|c|}{ Wheat equivalent } & \multicolumn{3}{|c|}{ Net profit } \\
\hline & $\begin{array}{l}\text { Before } \\
\text { conversion } \\
\text { period } \\
\text { average } \\
2004-05 \text { to } \\
2006-07\end{array}$ & $\begin{array}{l}\text { Mean } \\
\text { of } \\
2007- \\
2017\end{array}$ & $\begin{array}{c}\% \text { increase } \\
\text { over } \\
\text { conversion } \\
\text { period }\end{array}$ & $\begin{array}{c}\text { Before } \\
\text { conversion } \\
\text { period } \\
\text { average } \\
2004-05 \text { to } \\
2006-07\end{array}$ & $\begin{array}{c}\text { Mean } \\
\text { of } \\
2007- \\
2017\end{array}$ & $\begin{array}{c}\% \text { increase } \\
\text { over } \\
\text { conversion } \\
\text { period }\end{array}$ \\
\hline $\begin{array}{l}T_{1} 50 \% \text { NPK } \\
\text { fertilizer }+50 \% \text { through } \\
\text { FYM to both crops }\end{array}$ & 68.06 & 73.13 & 7.44 & 65419 & 73534 & 12.40 \\
\hline $\begin{array}{l}T_{2}-1 / 3 \mathrm{~N} \text { through FYM } \\
\text { vermicompost and Neem cake } \\
\text { to both the crops }\end{array}$ & 48.54 & 52.42 & 7.99 & 26439 & 27821 & 5.23 \\
\hline $\begin{array}{l}T_{3}-T_{2}+\text { Trap crop mustard in } \\
\text { wheat }\end{array}$ & 48.61 & 60.65 & 24.79 & 28520 & 38255 & 34.13 \\
\hline $\begin{array}{l}T_{4}-T_{2}+\text { Agronomic practices } \\
\text { of weed control of to both the } \\
\text { crops }\end{array}$ & 47.79 & 55.05 & 15.19 & 26419 & 27659 & 4.69 \\
\hline $\begin{array}{l}\mathrm{T}_{5^{-}} \mathbf{5 0 \%} \mathrm{N} \text { as } \mathrm{FYM}+\mathrm{PSB}+ \\
\text { rock phosphate+ Azatobactor }\end{array}$ & 49.76 & 49.97 & 4.22 & 38530 & 45832 & 18.95 \\
\hline $\mathrm{T}_{6}-\mathrm{T}_{2}+$ Azatobactor + PSB & 48.92 & 54.99 & 12.44 & 31027 & 32686 & 5.34 \\
\hline $\begin{array}{l}\mathrm{T}_{7}-100 \% \mathrm{NPK}+25 \mathrm{~kg} \\
\mathrm{ZnSo4} \text { based on soil test value }\end{array}$ & 69.17 & 81.42 & 17.70 & 65980 & 82820 & 25.52 \\
\hline
\end{tabular}


Table.3 Chemical properties of soil

\begin{tabular}{|c|c|c|c|c|c|c|}
\hline Treatment & $\begin{array}{l}\text { Soil } \\
\text { PH }\end{array}$ & $\begin{array}{l}\text { EC } \\
(\mathrm{Ds} / \mathrm{m})\end{array}$ & $\begin{array}{l}\text { OC } \\
(\mathrm{g} / \mathrm{kg})\end{array}$ & $\begin{array}{l}\text { N } \\
\text { Kg/ha }\end{array}$ & $\begin{array}{l}\mathrm{P} \\
\mathrm{Kg} / \mathrm{ha}\end{array}$ & $\begin{array}{l}\mathrm{K} \\
\mathbf{K g} / \mathbf{h a}\end{array}$ \\
\hline $\begin{array}{l}\mathrm{T}_{1} 50 \% \text { NPK through fertilizer }+50 \% \\
\mathrm{~N} \text { through FYM to both crops }\end{array}$ & 7.29 & 0.49 & 5.90 & 224 & $11.69+$ & 292 \\
\hline $\begin{array}{l}T_{2}-1 / 3 \quad N \quad \text { through FYM } \\
\text { vermicompost and Neem cake to both } \\
\text { the crops }\end{array}$ & 7.27 & 0.44 & $6.20+$ & $238+$ & $10.02+$ & 291 \\
\hline$T_{3}-T_{2}+$ Trap crop mustard in wheat & 7.27 & 0.45 & $6.10+$ & $231+$ & 9.66 & 288 \\
\hline $\begin{array}{l}T_{4}-T_{2}+\text { Agronomic practices of weed } \\
\text { control of to both the crops }\end{array}$ & 7.29 & 0.46 & 6.00 & 231 & 9.65 & 310 \\
\hline $\begin{array}{l}\mathrm{T}_{5^{-}} \mathbf{5 0 \%} \mathrm{N} \text { as } \mathrm{FYM}+\mathrm{PSB}+ \\
\text { rockphosphate+ Azatobactor }\end{array}$ & 7.26 & 0.45 & 630 & 227 & 9.28 & 305 \\
\hline$T_{6}-T_{2}+$ Azatobactor + PSB & 7.27 & 0.46 & 6.10 & 235 & 8.58 & 307 \\
\hline $\begin{array}{l}\mathrm{T}_{7}-100 \% \mathrm{NPK}+25 \mathrm{~kg} \mathrm{ZnSo4} \text { based } \\
\text { on soil test value }\end{array}$ & 7.30 & 0.50 & 5.80 & 219 & 8.58 & 309 \\
\hline Initial & 7.25 & 0.46 & 5.60 & 224 & 8.20 & 315 \\
\hline
\end{tabular}

The rate of increase in wheat equivalent yield was maximum $24.79 \%$ in $\mathrm{T}_{3}$ followed by $17.7 \%$ in $\mathrm{T}_{7}$ while it was lowest $7.44 \%$ in integrated nutrient management practices $\left(\mathrm{T}_{1}\right)$. Similar trend in net profit was also observed.

\section{(D) Effect on soil}

The chemical properties of soil after completion of 12 crop cycle have been given in Table 3. It is evident from the table that electrical conductivity and soil $\mathrm{pH}$ was not affected as compared to initial status. Organic carbon status was increase under different sources of nutrient management. The available nitrogen status was increased under organic and integrated nutrient management system while it was decreased in 100\% NPK given through fertilizer $\left(\mathrm{T}_{7}\right)$. Available phosphorus status was increase in $T_{1}$ and $T_{2}$ as compared to initial status. Available $\mathrm{K}$ status was decreased under all the cropping system as compared to initial status and maximum decrease were observed under $T_{1}$, $\mathrm{T}_{2}$ and $\mathrm{T}_{3}$.

\section{References}

Acharya CL, Bishnoi SK and Yaduvanshi HS. 1998. Effect of long term application of fertilizer and amendment under continuous cropping and soil references physical properties in Alfisols. Indian J. Agric. Sci., 58: 50 - 516.

Adikari P and Mishra BN. 2002. Effect of integrated $\mathrm{s}$. rtes of $\mathrm{N}$ on yield of aerobic rice and their residual feet on succeeding wheat. Int. Agrono. tong. November 26 -30, New Dehli.

Chakraborti Mandira and Singh NP. 2004. Bio-compost a novel input to the organic farming. Agrobios Newsletter, 2 (8): $14-15$.

Ciietry M and Bandhopadiwaya. 2005. Effect of integrated nutrient management on fertilizer use efficiency and change in soil fertility status under rice (Oryza sativa) based cropping system. Indian J. Agric. Sci. 75 (9): 596 - 599.

Khanda CM, Iviandai BK and Garnayak LM. 2005. Effect of integrated nutrient management on nutrient uptake and yield of component crops in rice (Oryza 
sativa) based cropping system. Indian J. Agron. 50: 1 - 5.

Kiiarub AS and Chander Subasii. 2008. Effect of organic ' farming on yield quality and soil fertility status under basmati rice (Oryza sativa) - wheat (Triticum aestivum) cropping system. Indian $\mathrm{J}$. Agri. Sci., 77 (8) 512-515.

Mankotia BS. 2007. Effect of fertilizer application with farm yard manures in standing rice (Oryza sativa) wheat (Triticum aestivum) cropping system. Indian J. Agri. Sci., 77 (8): 512-515.

Maurya BM, Dekate Jyoti and Upadhyay VB. 2010. Integrated nutrient management in rice wheat cropping system. JNKVV Res. J. 44 (1): 39-43.

Misiira, B. N. and Prasad R., 2000, Integrated nutrient management for sustained production in a rice-wheat cropping system. Acta. Agronomica Hungarica 48 (3): 257 - 262.

Singh AP, Tripathi RS and Mittra BN. 2000. Effect of integrated use of organic and chemical sources of nitrogen in rice wheat cropping system. Oryza, 37: 205 - 208.

Tarafdar JC, Tripatiii KP and Mvesh Kumar 2008. Organic Agriculture, Scientific Publishers, Jodhpur, p. 372.

\section{How to cite this article:}

Kurmvanshi, S.M., R.K. Tiwari, B.M. Maurya and Smita Singh 2018. Long Term Effect Organic, Inorganic and Integrated Nutrient Management on Rice-Wheat Cropping System. Int.J.Curr.Microbiol.App.Sci. 7(08): 1317-1322. doi: https://doi.org/10.20546/ijcmas.2018.708.149 